\title{
The Effect of the Implementation of Occupational Health and Safety Management Systems (SMK3) Against Security Tower Construction Project " $X$ " In Surabaya
}

\author{
Mansur \\ Engineering Faculty, Civil Engineering Study Program \\ Narotama University Surabaya, Jl. Arif Rahman Hakim 51, Sokolilo-Surabaya \\ (60117) \\ mansurrifai51@gmail.com \\ Fredy, KURNIAWAN \\ Engineering Faculty, Civil Engineering Study Program \\ Narotama University Surabaya, Jl. Arif Rahman Hakim 51, Sokolilo-Surabaya \\ (60117) \\ fredy@narotama.ac.id \\ Atik, WAHYUNI \\ Engineering Faculty, Civil Engineering Study Program \\ Narotama University Surabaya, Jl. Arif Rahman Hakim 51, Sokolilo-Surabaya
}

(60117)

\begin{abstract}
This study aims to analyze the effect of the implementation of the Occupational Safety and Health Management System (SMK3) on the productivity of workers on the "X" tower construction project in Surabaya. The population used is the employees of the tower construction project " $X$ " in Surabaya as many as 230 employees, while the number of samples taken 146 employees. The data used is sourced from primary data. Data collection is done by distributing questionnaires. The data analysis technique used is multiple linear regression analysis. The results in this study indicate that: (1) Safety Factor has a significant and positive influence on Project Security; (2) Equipment and Work Wear Factors have a significant positive effect on Project Security; (3) Vehicle Track Factors have a significant positive effect on Project Security; (4) Fire Factor has no significant effect on Project Security; (5) Equipment and Machine Factors have a significant positive effect on Project Security; (6) Electricity and Sound factors have a significant positive effect on Project Security; (7) Public Protection Factors have no significant effect on Project Safeguards; (8) General Factors have a significant positive effect on Project Security; (9) Occupational Health Factors have a significant positive effect on Project Security.
\end{abstract}

\section{Keywords}

Occupational Safety and Health Management System (SMK3), Worker Productivity

\section{INTRODUCTION}

Every year thousands of accidents occur in workplaces that cause casualties, material damage and production disruptions. In 2018 according to Jamsostek, there were 173,105 accidents that resulted in 1,451 deaths, 5,326 people with permanent disabilities and 58,697 injuries. The accident data includes all companies that are members of Jamsostek with around 7 million participants or about $10 \%$ of all workers in Indonesia. Thus the accident rate reaches 930 incidents for every 100,000 workers every year. Therefore the total number of accidents is estimated to be much larger. In fact, according to research from the world economic forum in 2006, the death rate due to accidents in Indonesia reached 17-18 for every 100,000 workers

Occupational safety and health must be managed as with other aspects of the company such as operations, production, logistics, human resources, finance and marketing. The K3 aspect will not be able to run as it is without intervention from management in the form of a planned effort to manage it. Therefore, since the early 1980s, K3 experts have tried to convince all parties, especially 
organizational management, to put the main $\mathrm{K} 3$ aspects on a par with other elements in the organization. This has led to the birth of various concepts regarding OSH management. According to Kepmenaker 05 of 1996, the Occupational Safety and Health Management System is part of an overall system which includes organizational structure, planning / design, responsibilities, implementation. The procedures, processes and resources required for the development, implementation, achievement, assessment and maintenance of occupational safety and health policies in controlling risks associated with project work activities in order to create a safe, efficient and productive workplace.

One of the obstacles that hinders the implementation of the Occupational Safety and Health Management System (SMK3) in construction projects is the assumption that the implementation of SMK3 in the constructionuses high fees and if an entrepreneur who cares about the safety of his employees, if he includes OSH costs in his bid document, is likely not to be the winner of the tender because the bid is definitely not the lowest bid. Work accidents also affect the human development index and national competitiveness. Therefore, in order to reduce the number of accidents and occupational diseases, the Ministry of Manpower is trying to improve the legislation and standards in the field of K3. Therefore, the government invites all employers, trade unions, workers and society to continue to raise awareness of the importance of $\mathrm{K} 3$.

Work safety is closely related to increasing production and productivity. Work safety can help increase production and productivity on the basis of: With a high level of safety, accidents that cause illness, disability and death can be minimized. A high level of safety is in line with the maintenance and use of productive and efficient work equipment and machines and is associated with high levels of production and productivity [1]. Thus, low occupational safety and health will certainly have an impact on work results that are less than optimal.

Productivity on a project is the volume produced by labor on a work item during a certain grace period. Increased productivity will reduce work time, and that means reduce project implementation costs. So far, construction operators have realized that the ups and downs of productivity in the implementation of construction projects are influenced by various factors. The labor factor is a top priority that must be considered in order to maintain good productivity, because labor is relatedlivewith project implementation. The productivity of the workforce will have an impact on the overall project performance. Project performance is the result of work in the form of building construction, from the productivity of all work generated by the workforce. Therefore, with the implementation of $\mathrm{K} 3$, the performance of construction projects will get better [2].

The implementation of $\mathrm{K} 3$ in the implementation of construction projects according to Bunial et al. (2018) consists of 9 factors, namely safety factors, equipment and work clothes factors, vehicle path factors, fire factors, equipment and machine factors, electricity and sound factors, protection factors public, general factors, and occupational health factors. The results of Bunial et al. (2018) research prove that the influence of $\mathrm{K} 3$ application factors on the performance of building construction projects in Aceh Province, which has a significant effect is the safety factor, work equipment and clothes, vehicle paths, equipment and machinery, public protection, general, the seriousness of the company, and the competence of workers. Desi Supriyan1 and lan Rico Andreas Ricardo's research also proved that the implementation of K3 management hasinfluencepositive and significant impact on the performance of project workers in the Cengkareng Business City Lot 5 project. Christina, Djakfar, \& Thoyib (2012) prove that the culture of occupational safety and health in construction projects needs to be developed because it greatly affects company performance. In connection with this research gap, the researcher wishes to analyze the effect of the implementation of the Occupational Health and Safety Management System (SMK3) on the security of the "X" tower construction project in Surabaya. The better the K3L implementation in the project, the higher the project security so that the project performance will run smoothly. Therefore, in this study, project security is measured by the project performance itself.

\section{THEORETICAL BASIS}

\subsection{Occupational Safety and Health (K3)}

Definition of Occupational Safety and Health (K3) according to the Kepmenaker RI No. Kep. 463 / MEN / 1993 is a protective measure aimed at ensuring that workers and other people in the workplace / company are always in a safe and healthy condition, and so that every source of production can be used safely and efficiently. Ervianto (2005) argues that occupational health and 
safety are two very important things. Therefore, all contracting companies are obliged to provide all necessary personal protective equipment / equipment.

\subsection{Definition of Occupational Health and Safety Management System (SMK3)}

According to PP. 50/2012, SMK3 is part of the company's overall management system in order to control risks related to work activities in order to create a safe, efficient and productive workplace. According to the ILO (International Labor Organization), SMK3 is a science that aims to anticipate, evaluate and control hazards that arise in and or from workplaces that can interfere with the health and welfare of workers, taking into account the possible impacts on the surrounding community and the general environment. Occupational safety and health management itself is the process of integrating or integrating the principles of occupational safety and health into a company system.

\subsection{Factors Associated with the Implementation of SMK3}

According to Bunial, Muttaqin, \& Rauzana (2018), the implementation of K3 in the implementation of construction projects consists of several factors. The factors can be seen in Table 2.1 .

Table 1. Factors of K3 Implementation

\begin{tabular}{|c|c|c|}
\hline No. & Factor & Indicator \\
\hline 1 & Safety factor & $\begin{array}{l}\text { Every worker in the project can reach the work place safely } \\
\text { Safety fences have been installed in open spaces in the project to prevent } \\
\text { falling workers } \\
\text { The project site is well lit. } \\
\text { Safety signs / signs have been installed in certain areas of the project } \\
\text { Temporary structures are in a stable and safe state }\end{array}$ \\
\hline 2 & $\begin{array}{l}\text { Equipment and } \\
\text { work clothes } \\
\text { factors }\end{array}$ & $\begin{array}{l}\text { The company provides work clothes, helmets, boots, gloves, masks, seat } \\
\text { belts } \\
\text { All the equipment is in good condition and can be used according to its } \\
\text { function } \\
\text { Workers use tools and work clothes when working } \\
\text { The company provides work clothes that can protect during rainy conditions }\end{array}$ \\
\hline 3 & $\begin{array}{l}\text { Vehicle path } \\
\text { factor }\end{array}$ & $\begin{array}{l}\text { There is a pedestrian lane separate from the lane for vehicles } \\
\text { There are different turning paths available to avoid one-way paths } \\
\text { All transport vehicles are in good condition or ready to use }\end{array}$ \\
\hline 4 & Fire factor & $\begin{array}{l}\text { There has been a smoking ban in the project area to avoid fire } \\
\text { There are sufficient fire extinguishers available } \\
\text { Limitations on the amount of combustible material have been imposed } \\
\text { A safe place is available for the storage area for flammable materials / } \\
\text { items } \\
\text { There has been a special disposal place for the remaining flammable } \\
\text { material / goods }\end{array}$ \\
\hline 5 & $\begin{array}{l}\text { Equipment and } \\
\text { machine } \\
\text { factors }\end{array}$ & $\begin{array}{l}\text { Selection of tools and machines according to the type of work } \\
\text { All parts of the equipment which are dangerous are protected } \\
\text { All machines can be operated properly } \\
\text { All operators are quite experienced and competent }\end{array}$ \\
\hline 6 & $\begin{array}{l}\text { Electrical and } \\
\text { sound factors }\end{array}$ & $\begin{array}{l}\text { All cable connections have been confirmed secure } \\
\text { All cables, both underground and ground level, are well protected } \\
\text { Sound absorbers are available at the project site } \\
\text { Ear protection is available at the project site }\end{array}$ \\
\hline 7 & $\begin{array}{l}\text { Public } \\
\text { protection } \\
\text { factor }\end{array}$ & $\begin{array}{l}\text { Fences have been installed around the project site } \\
\text { Project entrances and exits are in good condition } \\
\text { Signs / information about the project have been installed around the project } \\
\text { site }\end{array}$ \\
\hline 8 & $\begin{array}{l}\text { General } \\
\text { factors }\end{array}$ & $\begin{array}{l}\text { The company engages workers in training on work safety procedures } \\
\text { The company has clear rules regarding work safety procedures } \\
\text { The company imposes sanctions for violators of these regulations }\end{array}$ \\
\hline
\end{tabular}




\begin{tabular}{lll} 
No. & \multicolumn{1}{c}{ Factor } & \multicolumn{1}{c}{ Indicator } \\
\hline & $\begin{array}{l}\text { The company thoroughly identifies work accidents that have occurred } \\
\text { before } \\
\text { There are enough rescue routes as alternative routes in an emergency }\end{array}$ \\
9 Occupational & $\begin{array}{l}\text { Enough bathrooms are available } \\
\text { A picket duty has been implemented to clean the toilet facilities } \\
\text { There is a space to rest for the workers }\end{array}$ \\
& $\begin{array}{l}\text { There is a kitchen for workers to prepare food and drinks } \\
\text { Drinking water is available in sufficient quantities } \\
\text { Medicines are available for first aid in case of an accident }\end{array}$
\end{tabular}

Source: Wisandjojo (2013) in Bunial, Muttaqin, \& Rauzana (2018)

\section{RESEARCH METHODS}

This research uses a type of causality research with a quantitative approach. Research used by researchers is also more descriptive research (descriptive research). In this study, the population is 230 employees of the tower construction project "X" in Surabaya. The sampling technique used in this study was proportional sampling. So the sample used in this study were 146 employees of the tower construction project "X" in Surabaya who had worked for at least 1 year and with the consideration that employees who filled out the questionnaire were employees who really understood about construction projects. In this study, in order to obtain the required data, the authors used data collection through primary data sources. The primary data source used in this study is the questionnaire distribution method.Data analysis used in this research is multiple linear regression analysis, which aims to determine the effect of independent variables in the form of safety factors, equipment and work clothes factors, vehicle path factors, fire factors, equipment and machinery factors, electricity and sound factors, public protection factors, general factors, and occupational health factors to the dependent variable (project security).

\section{RESULTS AND DISCUSSION}

\subsection{Multiple Linear Regression Analysis}

The data analysis used in this study is multiple linear regression which is used to determine the factors that influence the implementation of the Occupational Safety and Health Management System (SMK3) in the tower construction project "X" in Surabaya. Based on the results of the calculation of data processing with the help of the SPSS for windows program computer, the multiple linear regression equation is obtained in Table 2.

Table 2. Results of Multiple Linear Regression Analysis

\begin{tabular}{lcc}
\hline \multicolumn{1}{c}{ Model } & Unstandardized Coefficients \\
& $\boldsymbol{B}$ & Std. Error \\
\hline Constant & 0.024 & 0.083 \\
Safety Factor (X1) & 0.121 & 0.056 \\
Equipment And Work Clothes Factor (X2) & 0.224 & 0.051 \\
Vehicle Path Factor (X3) & 0.104 & 0.046 \\
Fire Factor (X4) & 0.072 & 0.049 \\
Equipment and Machinery Factor (X5) & 0.172 & 0.042 \\
Electricity and Sound Factor (X6) & 0.082 & 0.041 \\
Public Protection Factor (X7) & 0.058 & 0.039 \\
General Factors (X8) & 0.128 & 0.061 \\
Occupational Health Factor (X9) & 0.156 & 0.061 \\
\hline
\end{tabular}

Based on the results of the above calculations, obtained a significant multiple linear regression equation as follows:

$$
\begin{aligned}
& \mathrm{Y}=0.024+0.121 \mathrm{X} 1+0.224 \mathrm{X} 2+0.104 \mathrm{X3}+0.072 \mathrm{X} 4+0.172 \mathrm{X} 5+0.082 \mathrm{X6}+0.058 \times 7+0.128 \\
& \mathrm{X8}+0.156 \times 9
\end{aligned}
$$

Where :

Y: Project Security

$\alpha$ : Constant

$\beta 1, . . \beta 9 \quad$ : Regression coefficient

$\mathrm{X} 1$ : Safety factor

$\mathrm{X} 2$ : Equipment and work clothes factors 
$\mathrm{X} 3$ : Vehicle path factor

X4 : Fire factor

$\mathrm{X} 5$ : Equipment and machine factors

$X 6$ : Electrical and sound factors

X7 : Public protection factor

X8 : General factors

X9 : Occupational health factors

The interpretation of the regression model above is as follows:

1) Constant $(\beta 0)=0.024$ which indicates the magnitude of the Project Security variable which is not influenced by the $\mathrm{K} 3$ application factor in the implementation of a construction project, or the independent variable $=0$, then the Project Security value is 0.024 , assuming other variables are constant.

2) The coefficient value of the Security Factor is 0.121 , indicating that if the security factor increases by one unit it will result in an increase in project security by 0.121 and vice versa if the security factor decreases by one unit it will result in a decrease in project security by 0.121 , assuming other variables are constant.

3) The coefficient value of the equipment and work clothes factor is 0.224 , indicating that if the equipment and work clothes factor increases by one unit it will result in an increase in project security by 0.224 and vice versa if the equipment and work clothes factor decreases by one unit it will result in a decrease in Project Security by 0.224, assuming other variables are constant.

4) The vehicle lane factor coefficient value is 0.104 indicating that if the vehicle lane factor increases by one unit it will result in an increase in Project Security by 0.104 and vice versa if the vehicle lane factor decreases by one unit it will result in a decrease in Project Security by 0.104 , assuming other variables are constant.

5) The fire factor coefficient value of 0.072 indicates that if the fire factor increases by one unit it will result in an increase in project security by 0.072 and vice versa if the fire factor decreases by one unit it will result in a decrease in project security by 0.072 , assuming other variables are constant.

6) The coefficient value of the equipment and machinery factor is 0.172 , indicating that if the equipment and machine factor increases by one unit it will result in an increase in project security by 0.172 and vice versa if the equipment and machine factor decreases by one unit it will result in a decrease in Project Security by 0.172 , assuming other variables are constant.

7) The coefficient value of the electricity and sound factor is 0.082 indicating that if the electricity and sound factors increase by one unit it will result in an increase in Project Security of 0.082 and vice versa if the electricity and sound factors decrease by one unit it will result in a decrease in Project Security by 0.082 , assuming other variables are constant .

8) The coefficient value of the public protection factor of 0.058 indicates that if the public protection factor increases by one unit it will result in an increase in project security by 0.058 and vice versa if the public protection factor decreases by one unit it will result in a decrease in project security by 0.058 , assuming other variables are constant.

9) The general factor coefficient value of 0.128 indicates that if the general factor increases by one unit it will result in an increase in project security by 0.128 and vice versa if the general factor decreases by one unit it will result in a decrease in Project Security by 0.128 , assuming other variables are constant.

10) The coefficient value of the occupational health factor of 0.156 indicates that if the occupational health factor increases by one unit it will result in an increase in Project Security by 0.156 and vice versa if the occupational health factor decreases by one unit it will result in a decrease in Project Security by 0.156 , assuming other variables are constant.

\subsection{Multiple Correlation Coefficient (R) and Multiple Determination (R2)}

Table 3. Correlation Coefficient and Coefficient of Determination

\begin{tabular}{rrrrr}
\hline Model & $\mathbf{R}$ & RSquare & Adjusted RSquare & Std. Error of Estimate \\
\hline 1 & $0.974 \mathrm{a}$ & 0.948 & 0.945 & 0.15782 \\
\hline
\end{tabular}


The value of the correlation coefficient $(R)$ shows how closely the relationship between the factors that influence the implementation of the Occupational Health and Safety Management System (SMK3) in the tower construction project " $\mathrm{X}$ " in Surabaya, the value of the correlation coefficient is 0.974. This value indicates that the relationship of all factors in this study with the Project Security $(\mathrm{Y})$ variable is very strong because the correlation value is 0.974 close to the number one.

The value of the coefficient of determination or R2 is used to measure how far the model's ability to explain variations in the dependent variable or dependent variable, namely the Project Security variable. The results of the SPSS calculation obtained a value of $R 2=0.948$, which means that $94.8 \%$ of Project Security can be explained by the Safety Factor (X1), Equipment and Work Clothes Factors (X2), Vehicle Path Factor (X3), Fire Factor (X4), Equipment Factor and Machinery (X5), Electrical and Sound Factor (X6), Public Protection Factor (X7), General Factor (X8), and Occupational Health Factor (X9). While the remaining $5.2 \%$ is influenced by other variables outside the model studied.

\subsection{F Test (Model Feasibility Test)}

The $\mathrm{F}$ test aims to test whether the independent variable is feasible in forming the dependent variable. Is the variable used is feasible when there is a significant effect or not when tested.

Table 4. Results of the F Test Calculation

\begin{tabular}{clrrrrr}
\hline Model & & Sum of Square & df & Mean Square & F & Sig \\
\hline 1 & Regression & 62,078 & 9 & 6,898 & 276,935 & 0.000 \\
& Residual & 3,387 & 136 & 0.025 & & \\
& Total & 65,465 & 145 & & & \\
\hline
\end{tabular}
mattershowingthat $\mathrm{HO}$ is rejected and $\mathrm{H} 1$ is accepted. So that the independent variable consisting ofSafety Factor (X1), Equipment and Work Wear Factor (X2), Vehicle Path Factor (X3), Fire Factor (X4), Equipment and Machinery Factor (X5), Electricity and Sound Factor (X6), Public Protection Factor (X7), General Factors (X8), and Occupational Health Factors (X9)effect simultaneously on variables Project Security $(\mathrm{Y})$.

\subsection{T test (partial test)}

To test the hypothesis, the $t$ test is used which shows the partial effect of each independent variable on the dependent variable. At this stage, testing is carried out on the effect of the independent variables in the formed model to determine whether the independent variable $(X)$ in the model partially has a significant effect on the dependent variable (y).

Table 5. T test results

\begin{tabular}{lcc}
\hline \multicolumn{1}{c}{ Variable } & T test \\
& Tstatistics & Sig \\
\hline Safety Factor (X1) & 2,169 & 0.032 \\
Equipment And Work Clothes Factor (X2) & 4,389 & 0.000 \\
Vehicle Path Factor (X3) & 2,245 & 0.026 \\
Fire Factor (X4) & 1,469 & 0.144 \\
Equipment and Machinery Factor (X5) & 4,055 & 0.000 \\
Electricity and Sound Factor (X6) & 2013 & 0.046 \\
Public Protection Factor (X7) & 1,502 & 0.135 \\
General Factors (X8) & 2,091 & 0.038 \\
Occupational Health Factor (X9) & 2,566 & 0.011 \\
\hline
\end{tabular}

1) T test (partial) on variables Safety factor (X1)

Based on the results of research data processing, the sig value is $0.032<0.05$, then $\mathrm{HO}$ is rejected at the $5 \%$ significance level so that the conclusion is that the Security Factor variable $(\mathrm{X} 1)$ has a significant and positive influence on Project Security.

2) $\quad T$ test (partial) on variables Equipment and Work Wear Factors (X2):

Based on the results of research data processing, the sig value is $0.000<0.05$, then $\mathrm{H} 0$ is rejected at the $5 \%$ significance level so that the conclusion is that the Equipment and Work Clothes Factor variable (X2) has a significant positive effect on Project Security.

3) $\quad T$ test (partial) on variables Vehicle Path Factor (X3):

Based on the results of research data processing, the sig value is $0.026<0.05$, then $\mathrm{HO}$ is rejected at the $5 \%$ significance level so that the conclusion is that the Vehicle Path Factor variable (X3) has a significant positive effect on Project Security. 
4) $\quad T$ test (partial) on variables Fire Factor (X4)

Based on the results of research data processing, the sig value is $0.144<0.05$, then $\mathrm{HO}$ is rejected at the $5 \%$ significance level so the conclusion is that the Fire Factor variable (X4) does not have a significant effect on Project Security.

5) T test (partial) on variables Equipment and Machinery Factor (X5):

Based on the results of research data processing, the sig value is $0.000<0.05$, then $\mathrm{HO}$ is rejected at the $5 \%$ significance level so that the conclusion is that the Equipment and Machinery Factor (X5) variable has a significant positive effect on Project Security.

6) T test (partial) on variables Electricity and Sound Factor (X6):

Based on the results of research data processing, the sig value is $0.046<0.05$, then $\mathrm{HO}$ is rejected at the $5 \%$ significance level so that the conclusion is that the Electricity and Sound Factor (X6) variables have a significant positive effect on Project Security.

7) T test (partial) on variables Public Protection Factor (X7)

Based on the results of research data processing, the sig value is $0.135<0.05$, then $\mathrm{HO}$ is rejected at the $5 \%$ significance level so that the conclusion is that the Public Protection Factor (X7) variable does not have a significant effect on Project Security.

8) $\quad T$ test (partial) on variables General Factors $(X 8)$ :

Based on the results of research data processing, the sig value is $0.038<0.05$, then $\mathrm{H} 0$ is rejected at the $5 \%$ significance level so that the conclusion is that the General Factor variable (X8) has a positive significant effect on Project Security.

9) T test (partial) on variables Occupational Health Factor (X9):

Based on the results of research data processing, the sig value is $0.011<0.05$, then $\mathrm{HO}$ is rejected at the $5 \%$ significance level so that the conclusion is that the Occupational Health Factor (X9) variable has a positive significant effect on Project Security.

\section{DISCUSSION}

\subsection{Effect of Safety Factors on Construction Project Security}

Based on the results of hypothesis testing through the $t$ test, it is found that the Safety Factor has a significant effect on Construction Project Security, as evidenced by the Sig value of 0.032 , by looking at these results it can be interpreted that good construction project security can be increased through the presence of a good safety factor.

Job security is an effort to safeguard and protect workers and their facilities / assets, both inside the office and outside the office environment. Efforts to provide job security guarantees are not only intended for workers who work in the office environment, but also for workers who work in the field, for example: Bank employees who are in charge of taking or delivering money to a place need to be closely guarded to anticipate crime [2].

These findings support the findings of Bunial et al. (2018) which prove that safety factors have a significant effect on the performance of building construction projects in Aceh Province. The same results were also proven by Bunial et al. (2018) who found in their research that Job Security affects performance.

\subsection{The Influence of Equipment and Work Clothes Factors on Construction Project Security}

Based on the results of hypothesis testing through the $t$ test, the results show that the Equipment and Work Clothes Factors have a significant effect on the Security of Construction Projects, as evidenced by the Sig value of 0.000 , by looking at these results it can be interpreted that good Construction Project Security is influenced by the presence of equipment and factors. supportive work clothes.

The results of the hypothesis testing show that the equipment and clothing factors can significantly influence the construction project security with a positive or unidirectional influence. This means that equipment and work clothes that support the work will increase the security of a construction project. However, this is not the same as the findings of research conducted by Bunial et al. (2018) where in their research it was proven that equipment and work clothes factors had a low relationship to construction project performance.

\subsection{The Influence of Vehicle Path Factors on Construction Project Security}

Based on the results of hypothesis testing through the $t$ test, the results show that the Vehicle Path Factor has a significant effect on Construction Project Security, as evidenced by the Sig value of 
0.026, by looking at these results it can be interpreted that a good Construction Project Security can be influenced by adequate vehicle paths and well.

The results of hypothesis testing proved that the vehicle lane factor was able to significantly influence the construction project security. In the results of hypothesis testing, it is also known that there is a positive influence between the two variables, which indicates that the better the existing vehicle lane, the more it will affect the level of security in the construction project. However, these findings are not the same as the findings of research conducted by Bunial et al. (2018) where in their findings it was found that vehicle lines had a low relationship to construction project performance.

\subsection{The Effect of Fire Factors on Construction Project Security}

Based on the results of hypothesis testing through the $t$ test, the results show that the Fire Factor does not have a significant effect on Construction Project Security, as evidenced by the Sig value of 0.144 , by looking at these results it can be interpreted that a good Construction Project Security cannot necessarily be influenced by the fire factor. happen.

The findings prove that the fire factor does not have a significant effect on construction project security but has a positive effect. This shows that the fire factor that is considered properly will be able to increase the security of the construction project but it will have little effect because it has an insignificant effect. This is in line with the research findings of Bunial et al. (2018) because in their research it was found that the fire factor had a very low relationship to the performance of construction projects.

\subsection{The Effect of Equipment and Machinery Factors on Construction Project Security}

Based on the results of hypothesis testing through the $t$ test, the results show that the Equipment and Machinery Factors have a significant effect on Construction Project Security, as evidenced by the Sig value of 0.000 , by looking at these results it can be interpreted that good Construction Project Security can be increased influenced by the presence of equipment factors. and supporting machines.

A high level of safety is in line with the maintenance and use of productive and efficient work equipment and machines and is associated with high levels of production and productivity [4]. Thus, low occupational safety and health will certainly have an impact on work results that are less than optimal. However, these results reject the research findings of Bunial et al. (2018) which prove in their research that equipment and machinery have a low relationship to the performance of building construction projects in Aceh Province.

\subsection{The Effect of Electricity and Sound Factors on Construction Project Security}

Based on the results of hypothesis testing through the $t$ test, the results show that the Electricity and Sound Factors have a significant effect on the Security of Construction Projects, as evidenced by the Sig value of 0.046 . which exists.

Based on the results of the analysis, it is proven that the electricity and sound factors have a significant effect on the security of construction projects. By looking at these results, it can be interpreted that the more attention is paid to the electricity and sound factors in a construction project, the more it will be able to increase the level of construction project security. The findings in this study do not support the research findings of Bunial et al. (2018) where in their research it was found that different results were that electricity and sound had a very low relationship to the performance of building construction projects.

\subsection{The Effect of Public Protection Factors on Construction Project Security}

Based on the results of hypothesis testing through the $t$ test, the results show that the Public Protection Factor does not have a significant effect on Construction Project Security, as evidenced by the Sig value of 0.135 , by looking at these results it can be interpreted that good Construction Project Security is not influenced by the existence of public protection factors. .

The findings prove that the public protection factor has a positive but insignificant effect on the security of construction projects. This indicates that the public protection factor can affect the level of security in a construction project but it is very low because the results obtained are not significant. This is also supported by the research findings of Bunial et al. (2018) where their findings prove that public protection has a very low relationship to the performance of building construction projects. 


\subsection{The Effect of General Factors on Construction Project Security}

Based on the results of hypothesis testing through the $t$ test, it is found that the General Factors have a significant effect on the Security of Construction Projects, as evidenced by the Sig value of 0.038 , by looking at these results it can be interpreted that good Construction Project Security can be increased by the presence of general supporting factors.

The results of the analysis show that general factors are able to significantly influence project security positively. This means that the general factor that is getting better in a construction project will be able to make a big contribution in influencing the level of security in a construction project. However, this is in contrast to the findings of research conducted by Bunial et al. (2018) which prove that general factors have a very low relationship to construction project performance.

\subsection{The Influence of Occupational Health Factors on Construction Project Security}

Based on the results of hypothesis testing through the $t$ test, it is found that the Occupational Health Factor has a significant effect on the Security of Construction Projects, as evidenced by the Sig value of 0.011 , by looking at these results it can be interpreted that good Construction Project Security can be influenced by the level of occupational health factors support.

The results of the analysis proved that there was a significant positive effect between occupational health factors and construction project security. This may imply that the level of occupational health factors that are being paid more attention will increase the security of the construction project as it progresses. According to Mangkunegara (2013), the occupational health program shows conditions that are free from physical, mental, emotional or pain disorders caused by the environment. Health risks are factors in the work environment that work beyond the specified time period. The environment can create emotional distress or physical distress.

\section{CONCLUSION}

Based on the analysis and research results obtained, the conclusions in this study are as follows:

1. The safety factor has a significant effect on the security of the "X" tower construction project in Surabaya

2. Equipment and work clothes factors have a significant effect on the security of the "X" tower construction project in Surabaya

3. Vehicle lane factors have a significant effect on the security of the "X" tower construction project in Surabaya

4. The fire factor does not have a significant effect on the security of the "X" tower construction project in Surabaya

5. Equipment and Machinery Factors have a significant effect on the Security of "X" Tower Construction Projects in Surabaya

6. Electricity and sound factors have a significant effect on the security of the " $\mathrm{X}$ " tower construction project in Surabaya

7. The Public Protection Factor does not have a significant effect on the Security of the "X" tower construction project in Surabaya

8. General factors have a significant effect on the security of the "X" tower construction project in Surabaya

9. Occupational Health factors have a significant effect on the Security of the " $X$ " tower construction project in Surabaya.

\section{SUGGESTION}

Based on the results of the analysis and discussion conducted, the researcher provides several suggestions that can contribute to improving Security for the Construction Project for tower "X" in Surabayaas well as for further research. The suggestions are as follows:

1. The "X" tower construction project in Surabaya is increasingly paying attention to the fire factor in an effort to improve project security so that workers will be able to work in a safe environment.

2. Future research is expected to add or develop other variables apart from the variables used in this study which are thought to affect Project Security and use other methods such as qualitative. 


\section{References}

[1] Suma'mur, Higiene Perusahaan dan Kesehatan Kerja. Jakarta: Sagung Seto, 2013.

[2] B. Bunial, M. Muttaqin, and A. Rauzana, "Faktor-Faktor Penerapan Keselamatan Dan Kesehatan Kerja Yang Mempengaruhi Kinerja Proyek Konstruksi Gedung Di Provinsi Aceh,” J. Arsip Rekayasa Sipil dan Perenc., vol. 1, no. 4, pp. 130-137, Dec. 2018, doi: 10.24815/jarsp.v1i4.12463.

[3] W. Y. Christina, L. Djakfar, and A. Thoyib, "Pengaruh Budaya Keselamatan Dan Kesehatan Kerja (K3) Terhadap Kinerja Proyek Konstruksi,” J. REKAYASA SIPIL, vol. 6, no. 1, pp. 83-95, 2012.

[4] Suma'mur, Company Hiegiene and Work Safety. Jakarta: Sagung Seto, 2009.

[5] Mangkunegara, Manajemen Sumber Daya Manusia. Bandung: Remaja Rosdakarya, 2013. 